Volume 7 No. 2, Juli-Desember 2020

P-ISSN: 2406-808X // E-ISSN: 2550-0686

https://journal.iainlangsa.ac.id/index.php/ikhtibar

https://doi.org/10.32505/ikhtibar.v7i2.619

\title{
Tradisi Meuulang (Muthala'ah) Dalam Meningkatkan Interaksi Individual (Pendekatan Santri dan Teungku) Studi Kasus di Dayah Darul Huda Lueng Angen
}

\author{
Mawaddah, Muhammad Nuh Rasyid, Lathifah Hanum \\ Institut Agama Islam Negeri Langsa \\ muhammadnuhrasyid@iainlangsa.ac.id
}

\begin{abstract}
Abstrak
Latar belakang dari penelitian ini adalah dalam lingkungan dayah atau pesantren,antara guru dan santri biasanya terdapat batasan. Terutama dalam interaksi di dalam kelas. Karena interaksi teungku dan santri, sangat dibutuhkan untuk mengetahui bagaimana kemajuan santrinya dalam proses belajar. Sebagian besar santri pada saat proses belajar berlangsung, masih terlihat sulit dalam mengembangkan diri, mengeluarkan pendapat, ide dan kurang percaya diri ketika menyampaikan sesuatu. Maka dari itu, diperlukan metode yang sesuai agar santri lebih tertarik dan bersemangat untuk mengikuti pelajaran salah satunya dengan metode yang dalam penelitian ini ditulis oleh peneliti sebagai metode meuulang (muthala'ah). Tujuan pokok dalam penelitian ini untuk mengetahui tradisi meuulang (muthala'ah) dalam meningkatkan interaksi individual (pendekatan santri dan teungku) studi kasus di Dayah Darul Huda Lueng Angen, Kec. Langkahan Aceh Utara. Jenis penelitian yang digunakan dalam penelitian ini adalah penelitian lapangan (fildresearch) bersifat deskripif kualitatif, dalam penelitian ini peneliti hanya mengambil $13 \%$ dengan jumlah 10 santri kelas 1 untuk diwawancarai di dayah Darul Huda Lueng Angen. Data dikumpulkan menggunakan observasi, wawancara dan dokumentasi. Peneliti menggunakan analisis data dengan teknik analisis yang meliputi reduksi data, pengajian data dan verifikasi (menarik kesimpulan). Hasil dari penerapan metode meuulang (muthala'ah) dalam meningkatkan interaksi individual menunjukkan bahwa perkembangan interaksi semakin meningkat, komunikasi mulai terjalin serta pemahaman kitab-kitab mata pelajaran sangat terbantu dengan metode meuulang (muthala'ah).
\end{abstract}

Kata Kunci : Interaksi Individual, Meuulang (Muthala'ah)

\section{Pendahuluan}

Pendidikan mempunyai peranan penting dalam membangun kecerdasan serta kepribadian anak manusia menjadi lebih baik. Oleh karena itu, pendidikan secara terus menerus dibangun dan dikembangkan agar dari proses 
pelaksanaannya menghasilkan generasi yang diharapkan. Pendidikan nasional berdasarkan Pancasila dan Undang-Undang Dasar Negara Republik Indonesia Tahun 1945.

Pendidikan nasional berfungsi mengembangkan kemampuan, membentuk watak serta peradaban bangsa yang bermartabat dalam rangka mencerdaskan kehidupan bangsa. Diharapkan, potensi peserta didik menjadi manusia yang beriman dan bertaqwa kepada Tuhan Yang Maha Esa, berilmu, cakap, kreatif, mandiri, dan menjadi warga negara yang demokratis serta bertanggung jawab. ${ }^{1}$

Untuk Aceh, bertolak dari landasan yuridis secara nasional tentang penyelenggaraan pendidikan. Proses penyelenggaraan pendidikan di Aceh diatur melalui Perda No. 6 tahun 2000, Qanun No 23 Tahun 2002, Undang-Undang No 44 tahun 1999 tentang keistimewaan bidang pendidikan. Dalam Qanun Penyelenggaraan Pendidikan No. 23. Tahun 2002 lembaga pendidikan dayah di Aceh termasuk jalur pendidikan non formal. ${ }^{2}$

Dayah merupakan sebuah wadah lembaga pendidikan Islam tempat mempersiapkan santri-santri agar mengetahui dan mengamalkan ajaran Islam dengan baik dan sempurna. Dayah juga mampu mendidik santrinya menjadi ulama, sehingga dengan kehadiran ulama mampu menjadi lampu penerang dan panutan bagi masyarakat. Dayah ialah sebutan dikalangan masyarakat Aceh khususnya, masyarakat lebih mengenal istilah dayah daripada pesantren. ${ }^{3}$

Seperti Dayah Darul Huda, di Desa Krueng Lingka Lueng Angen Kecamatan Langkahan Aceh Utara, merupakan salah satu dayah salafi murni di Aceh. Pesantren didirikan oleh Tengku Muhammad Daud Ahmad, 27 April 1972 silam. Saat itu, Abu baru saja selesai menimba ilmu dipesantren Samalanga. Kala itu, diatas tanah $40.000 \mathrm{M} 2$ itu hanya berdiri satu balai pengajian ukuran 4 x 7 meter. Mulai dari situlah, Abu memulai kegiatan mengajar para santri dan kemudian beliau mencari dukungan masyarakat untuk kemajuan pesantren hasilnya lumayan memadai. ${ }^{4}$

Hingga saat ini, bangunan tiga tingkat dengan kontruksi beton berdiri megah di Desa Krueng Lingka Lueng Angen. Satu buah mesjid tempat ibadah juga berdiri megah dengan desain taman yang indah ditambah lagi dengan asrama santriwan/i dan rumah para dewan guru. Dua orang anak Abu Muhammad Daud Ahmad yaitu Muzakkir dan Zainab, juga turut membantu pengembangan pesantren itu.

Awal mula aktif tahun 1972 tepatnya sarana belajar berupa balai selesai dibuat. Dengan jumlah santri mulanya 50 orang dan terus meningkat setiap tahunnya. Sehingga pada tahun 1976 saat dayah telah berusia tiga tahun, jumlah santrinya telah mencapai 461 orang terdiri 275 santriwan dan 186 santriwati.

\footnotetext{
${ }^{1}$ Mukhlisuddin Ilyas, Pendidikan Dayah Aceh: Mulai Hilang Identitas, (Banda Aceh: Bandar Publishing, 2012), hal. 1

Ibid., hal. 5-6

${ }^{3}$ Departemen Agama RI, Profil Pondok Pesantren Mu'adalah, (Jakarta: Direktorat Pendidikan Keagamaan dan Pondok Pesantren, 2004), hal.7

${ }^{4}$ Tgk Mustafa Idris, Umdah: KB Dalam Pandangan Islam, (Samalanga: edisi XII, 2016), hal. 58
} 
Kemudian pada tahun 2010 santri yang mondok di dayah berjumlah 2.667 orang, terdiri dari 1.333 orang santriwan dan 1.334 orang santriwati. ${ }^{5}$

Saat ini pesantren memiliki 4. 249 orang santri dan didik oleh 422 teungku/guru serta 200 orang ustadzah yang sangat memadai. Tujuan pendidikan dayah salafi ini untuk mencerdaskan santri untuk mengkaji dan mendalami ilmu agama tentunya dengan penekanan pada kitab kuning (kitab gundul).

Dalam ranah pendidikan dayah Darul Huda Lueng Angen, Kec Langkahan Aceh Utara, menyampaikan ilmu tentunya memiliki berbagai macam metode pembelajaran. Agar santri nantinya tidak merasa jenuh dengan penggunaan metode yang sama saja, maka dibuatlah salah satunya ialah dengan menggunakan metode meuulang (muthala'ah). Metode ini dibimbing oleh seorang teungku atau santri yang senior yang dipilih oleh santri untuk membimbingnya. ${ }^{6}$

Metode meuulang(muthala'ah) dapat dikatakan salah satu metode yang sudah sangat lama diterapkan didayah Darul Huda Lueng Angen, Kec Langkahan Aceh Utara. Bila kita mendengar pengalaman para tuan-tuan guru mulia yang saat ini sudah menjadi panutan umat, keberhasilan seorang lulusan dayah sangat dititik beratkan kepada meuulang (muthala'ah) disaat dalam masa menjadi santri. Maka keberhasilan metode meuulang (muthala'ah) ini sudah tidak diragukan lagi.

Prosedur pelaksanaan metode meuulang (muthala'ah) ialah, teungku/guru membaca kitab yang disediakan oleh santri kemudian menerjemahkannya, menggunakan bahasa Indonesia atau bahasa Aceh, banyak sedikitnya bacaan kitab yang diterjemahkan teungku/guru tergantung kemampuan tingkat kecerdasan dan daya ingat santri. Selain membaca dan menerjemah teungku/guru juga menjelaskan isi dari kitab yang dibacanya. Dalam lingkup meuulang (muthala'ah) teungku atau santri senoir itu disebut sebagaiguree peu ulang. ${ }^{7}$

Beragam problematika dihadapi oleh teungku/guru atau gure peuulang, dalam menghadapi santri dengan berbagai macam karakter terutama bagi santri yang baru masuk pendidikan dayah, dikarenakan pelaksanaannya meuulang (muthala'ah) dilakukan pada saat sudah larut malam. Tentunya butuh kemampuan tersendiri dan butuh adanya interaksi individual antara teungku dan santri agar pembelajaran dapat berlangsung dengan baik, kemudian problematika juga hadir akan kurangnya motivasi santri dalam meuulang (muthala'ah) sehingga meuulang (muthala'ah) dilakukan sekedar melepas kewajiban saja, walaupun saat meuulang (muthala'ah) nanti hasilnya nihil. Teungku/guru atau gure peuulang berkewajiban untuk meningkatkan kesadaran akan pentingnya belajar dan meuulang (muthala'ah) serta akibat-akibat yang diterimanya nanti jika mengabaikan belajar.

Alasan peneliti memilih judul ini karena berdasarkan survei peneliti melihat beberapa santri masih belum efektif dalam meuulang (muthala'ah) terutama santri yang berstatus baru, bahkan santri banyak yang tidak serius dalam mengikuti proses meuulang(muthala'ah), terlihat meuulang(muthala'ah) seperti dijadikan beban terberat karena dilaksanakan pada waktu larut malam, dan sangat dibutuhkan interaksi individual agar proses meuulang (muthala'ah) mampu

${ }^{5}$ Ibid., hal. 60

hal. 17

${ }^{6}$ Tajussubki Abdullah, Umdah: Hukum Wanita Musafir, (Samalanga: edisi XIV, 2017),

${ }^{7}$ Ibid., hal. 18 
membangun kedekatan dengan teungku/guru atau gure peuulang sehingga pencapaian yang diharapkan terwujud.

Adapun interaksi individual diterapkan pihak dayah terutama dalam proses meuulang(muthala'ah), agar santri mampu menimalisir terutama kendala yang dihadapi dalam belajar dan kedekatan antara dengan sang guru mampu meningkatkan dan menumbuhkan kesadaran dalam jiwa santri akan pentingnya meuulang (muthala'ah).

Berdasarkan latar belakang yang telah diuraikan di atas, penulis menarik untuk meneliti tentang “Tradisi Meuulang (Muthala'ah) Dalam Meningkatkan Interaksi Individual (Pendekatan Santri Dan Teungku) Studi Kasusdi Dayah Darul Huda Lueng Angen, Kec LangkahanAceh Utara Tahun ajaran 20182019".

\section{Metode Penelitian}

Jenis penelitian yang digunakan dalam penelitian ini adalah penelitianlapangan (field research) yang bersifat deskripif kualitatif dengan jenis pendekatan deskriptif, artinya penelitian yang berusaha mendefinisikan suatu gejala, peristiwa, kejadian yang terjadi saat sekarang atau mengambil masalahmasalah yang memusatkan perhatian kepada masalah-masalah yang aktual sebagaimana adanya saat penelitian yang berlangsung dilaksanakan. ${ }^{8}$

Kemudian Moh. Nazir menjelaskan tentang metode penelitian deskriptif yaitu suatu metode dalam meneliti status kelompok manusia, suatu objek, suatu sistem pemikiran ataupun suatu kelas peristiwa pada masa sekarang. ${ }^{9}$ Jenis data deskriptif hanya digunakan untuk mendeskripsikan data yang telah terkumpul. Tujuan dari penelitian adalah untuk mengetahui penerapan metode meuulang (muthala'ah) dalam meningkatkan interaksi individual antara santri dan teungku atau gure peuulang.

Untuk mendapatkan data yang berkaitan dengan penelitian ini, maka diperlukan beberapa teknik pengumpulan data sebagai berikut:

\section{Observasi (Pengamatan)}

Observasi adalah pengamatan dan pencatatan dengan sistematik fenomena-fenomena yang diselidiki. Observasi yaitu seorang peneliti akan melakukan pengamatan dan peninjauan langsung ke lokasi penelitian untuk memperoleh informasi. ${ }^{10}$ Kegunaan Observasi adalah untuk memperoleh informasi tentang penerapan metode meuulang (muthala'ah) untuk meningkatkan interaksi antara santri dan teungku atau gure peuulang di Dayah Darul Huda Lueng Angen, Kec LangkahanAceh Utara. Selain memperoleh informasi, penulis menggunakan observasi untuk memperoleh gambaran tentang strategi yang digunakan teungku atau gure peuulang dalam menambah daya tarik minat belajar santri pada metode meuulang (muthala'ah).

\section{Wawancara}

Wawancara merupakan metode pengumpulan data yang dilakukan melalui tanya jawab lisan kepada subjek atau responden yang dipandang berhubungan

\footnotetext{
${ }^{8}$ Sudjana, Nana. Dkk, Penelitian dan Nilai, (Bandung: Pendidikan Sinar, 1989), hal. 46

${ }^{9}$ Moh. Nazir, Metode Penelitian, (Bogor: Ghalia Indonesia, 1983), hal. 54

${ }^{10}$ Sukardi, Metodologi Penelitian Pendidikan, (Jakarta: PT Bumi Aksara, 2009), hal. 6
} 
dengan objek yang diperlukan dalam kegiatan. ${ }^{11}$ Metode wawancara (interview) adalah cara pengumpulan bahan-bahan keterangan yang dilakukan tanya jawab lisan secara sepihak, berhadapan muka dengan arah dan tujuan yang telah ditentukan. ${ }^{12}$ Wawancara merupakan suatu teknik pengumpulan data penelitian melalui percakapan dan pengamatan yang bertujuan untuk memperoleh keterangan tentang objek penelitian. Dalam penelitian ini, penulis akan mewawancarai sebanyak 10 santri untuk mendapatkan keterangan tentang asumsi santri terhadap metode meuulang (muthala'ah) yang telah diterapkan oleh pihak dayah Darul Huda Lueng Angen, Kec LangkahanAceh Utara dan sejauh mana interaksi santri dengan teungku sebagai gure peuulang.

\section{Dokumentasi}

Dokumentasi merupakan metode pengumpulan data yang digunakan untuk mencari data mengenai hal-hal atau variabel yang berupa catatan dokumen, transkrip buku, surat kabar, majalah, prestasi, notulen rapat, agenda dan sebagainya. ${ }^{13}$ Dokumentasi merupakan pelengkap dari penggunaan metode observasi dan wawancara dalam penelitian kualitatif.

Jadi, peneliti mencari data yang diperlukan sebagai penunjang kevalidan akan penelitiannya yaitu dengan cara mencari dokumen-dokumen yang berkaitan dengan sejarah di Dayah Darul Huda di Desa Krueng Lingka Lueng Angen, Kecamatan Langkahan, Kabupaten Aceh Utara, foto ketika penulis mengadakan proses wawancara dan kegiatan-kegiatan yang lain.

\section{Hasil dan Pembahasan Penelitian}

\section{Hasil Wawancara}

\section{a. Interaksi Santri dan Teungku di Dayah Darul Huda Lueng Angen}

Berikut ini akan dipaparkan secara jelas hasil analisis transkrip wawancara peneliti terhadap beberapa informan terkait dengan interaksi santri dan teungku di Dayah Darul Huda Lueng Angen.

Dalam kaitannya dengan interaksi santri dan teungku di Dayah Darul Huda Lueng Angen, Tgk Muhktar selaku anak pertama dari Abu Lueng Angen, dan beberapa dewan guru yang peneliti wawancarai mengatakan seperti ini:

"Interaksi yang terjadi antara santri biasanya terjadi Adanya motivasi yang tinggi dari santri untuk belajar adalah salahsatu indikator keberhasilan interaksi yang terjadi didalam kelas. Salah satu keterampilan teungku adalah dapat berinteraksi atau berkomunikasi dengan baik didalam kelas, contohnya adalah teungku membacakan kitab sesuai dengan jadwal yang telah ditentukan pada masa meuulang (muthala'ah) khususnya, setelah itu teungku

\footnotetext{
${ }^{11}$ Bambang Setiyadi, Metode Penelitian untuk Pengajaran Bahasa Asing Pendekatan Kuantitatif dan Kualitatif, (Yogyakarta: Graha Ilmu, 2006), hal. 239

${ }^{12}$ Anas Sudjiono, Pengantar Statistik Pendidikan, (Jakarta: Rajawali Press, 2002), hal. 36

${ }^{13}$ Suharsimi Arikunto, Prosedur Penelitian..., hal. 124
} 
memberikan peluang kepada santri untuk bertanya jika tidak ada yang bertanya maka guru akan bertanya kepada santri". ${ }^{14}$

Kemudian peneliti mewawancarai Tgk. Manskur, beliau mengatakan:

"jika gure peuulang dapat berinteraksi baik, pasti timbal balik itu ada, tetapi jika sebaliknya, gure peuulang tidak dapat berinteraksi dengan baik pada saat proses meuulang (muthala'ah), maka yang terjadi adalah proses meuulang (muthala'ah) merosot, sehingga merugikan diri sendiri. Didalam proses meuulang (muthala'ah), jika dalam bentuknya bercanda, maka hendaklah sewajarnya saja sekedar refresh dalam proses belajar sehingga terkesan tidak menjadi beban". ${ }^{15}$

Peneliti juga mewawancarai Tgk Rohana, mengatakan:

"Interaksi individual yang terjadi dalam proses meuulang (muthala'ah), di Dayah Darul Huda Lueng Angen diupayakan interaksi 2 arah atau multi arah, karena sangat mempengaruhi keberhasilan maka dalam melakukan interaksi individual di dalam kelas guru harus punya pengalaman mendidik sesuai dengan eranya". ${ }^{16}$

Selanjutnya, wawancara pimpinan Tgk. H. Muhammad Jafar menjelaskan:

"Teungku dalam memberikan pelajaran dengan interaksi individual sangat berpengaruh terhadap santri, membuat siswa senang dalam mengikuti pelajaran, karena didalam pelajaran gure peuulang mempermudah pelajaran yang disampaikan dengan menggunakan contoh yang ada dalam kehidupan sehari-hari sebagai interaksi didalam kelas". ${ }^{17}$

Selain dewan guru, peneliti juga mewawancarai santriwati Ys dan Mh, perihal interaksi yang terjadi didalam kelasmeuulang (muthala'ah) antara guru kepada mereka mereka menyatakan bahwa:

"Didalam kelas meuulang(muthala'ah) Guru menerangkan didalam kelas dengan sangat jelas dan runtut. Disertai dengan contohnya. Contohnya pun sangat dekat dengan kehidupan mereka sehingga mudah di tangkap oleh mereka. Kami mudah akrab dan terbuka dengan teungku semasa meuulang". ${ }^{18}$

\footnotetext{
${ }^{14}$ Hasil wawancara Tgk. Muhktar, Sabtu 05 Oktober 2019 "Tradisi Meuulang (Muthala'ah) Dalam Meningkatkan Interaksi Individual (Pendekatan Santri dan Teungku) di Dayah Darul Huda Lueng Angen, Kec. Langkahan Aceh Utara”

${ }^{15}$ Hasil wawancara Tgk. Manskur, Sabtu 05 Oktober 2019 "Tradisi Meuulang (Muthala'ah) Dalam Meningkatkan Interaksi Individual (Pendekatan Santri dan Teungku) di Dayah Darul Huda Lueng Angen, Kec. Langkahan Aceh Utara”

${ }^{16}$ Hasil wawancara Tgk. Rohana, Sabtu 05 Oktober 2019 "Tradisi Meuulang (Muthala'ah) Dalam Meningkatkan Interaksi Individual (Pendekatan Santri dan Teungku) di Dayah Darul Huda Lueng Angen, Kec. Langkahan Aceh Utara”

${ }^{17}$ Hasil wawancara Tgk. H. Muhammad Jafar, Minggu 06 Oktober 2019 "Tradisi Meuulang (Muthala'ah) Dalam Meningkatkan Interaksi Individual (Pendekatan Santri dan Teungku) di Dayah Darul Huda Lueng Angen, Kec. Langkahan Aceh Utara”

${ }^{18}$ Hasil wawancara dengan santriwati Ys dan Mh, Sabtu 05 Oktober 2019 "Tradisi Meuulang (Muthala'ah) Dalam Meningkatkan Interaksi Individual (Pendekatan Santri dan Teungku) di Dayah Darul Huda Lueng Angen, Kec. Langkahan Aceh Utara”
} 
Berdasarkan pernyataan-pernyataan diatas, dapat disimpulkan bahwa interaksi santri dan teungku/guru di Dayah Darul Huda Lueng Angen berlangsung disebabkan adanya:

(1) Motivasi yang tinggi dari santri untuk belajar adalah salah satu indikator keberhasilannya interaksi.

(2) Keterampilan teungku dalam berinteraksi atau berkomunikasi dengan baik selama proses belajar mengajar berlangsung.

(3) Kerjasama antara santri dan teungku dalam pemecahan masalah

(4) Kebutuhan inklusi (individu mulai berpatisipasi dan bersosialisasi dengan lingkungannya) individu yang tidak terpenuhi kebutuhan inklusinya cenderung berperilaku malu, menarik diri, sulit menyesuaikan diri dan sulit bekerja sama dengan orang lain.

(5) Kebutuhan akan dorongan dan arahan (kontrol) dari orang lain dalam menyelesaikan setiap persoalan yang dihadapi.

(6) Kebutuhan afeksi merupakan kebutuhan dimana seseorang mendapatkan kasih sayang dan perhatian dari orang lain agar dapat diterima di dalamkelompok. Kebutuhan afeksi ini tercermin dengan timbulnya perasaan suka atau tidak suka dengan orang lain.

(7) Adanya kontak sosial, hubungan antara individu satu dengan individu yang lain yang bersifat langsung, seperti dengan sentuhan, percakapan, maupun tatap muka sebagai wujud aksi dan reaksi.

\section{b. Peran Teungku/guru Dalam Memberikan Pelajaran di Dayah Darul Huda Lueng Angen}

Berikut ini akan dipaparkan secara jelas hasil analisis transkip wawancara peneliti terhadap beberapa informan terkait dengan peran teungku/guru dalam memberikan pelajaran di Dayah Darul Huda Lueng Angen

Dalam kaitannya dengan peran teungku dalam memberikan pelajaran, Tgk. Manskur selaku staf pengajar di Dayah Darul Huda Lueng Angen memaparkan:

"Adanya kerjasama dalam interaksi antara teungku dan santri di Dayah Darul Huda yakni ketika berdiskusi teungku sebagai pembimbing, sebagai fasilitator, dan sebagai narasumber jika santri tidak dapat memecahkan masalah yang sedang didiskusikan. Maka timbal balik adalah salah satu efek dari adanya kerjasama teungku dan santri dalam berinteraksi". ${ }^{19}$

Selanjutnya peneliti mewawancarai tentang peran teungku/guru dalam memberikan pelajaran di Dayah Darul Huda Lueng Angen, Tgk. Syahrial, mengungkapkan:

"Peran dalam lingkup pembelajaran,bisa dikatakan teungku/guru tidak hanya menjadi pendidik. Namun teungku/guru harus mampu menjadi pembimbing, pelatih, penasehat dalam memberikan pelajaran selama proses belajar mengajar. Terutama di Dayah Darul Huda

\footnotetext{
${ }^{19}$ Hasil wawancara Tgk. Manskur, Sabtu 05 Oktober 2019 "Tradisi Meuulang (Muthala'ah) Dalam Meningkatkan Interaksi Individual (Pendekatan Santri dan Teungku) di Dayah Darul Huda Lueng Angen, Kec. Langkahan Aceh Utara”
} 
Lueng Angen ini, setiap yang dinobatkan menjadi teungku/guru harus menyelesaikan pendidikan kejenjang 10 dan telah lulus seleksi kelayakan sesuai bidang masing-masing. Seleksi ini dilakukan agar terhindar dari kualitas abal-abal sehingga teungku/guru sangat difilterkan pada tahap ini ${ }^{20}{ }^{20}$

Peneliti juga mewawancarai, Tgk Rahayu terkait peran teungku/guru dalam memberikan pelajaran di Dayah Darul Huda Lueng Angen, mengatakan:

"Setiap teungku/guru seharusnya mampu menjadi teladan seperti yang telah terdapat dalam peraturan-peraturan teungku/guru yang dibuat oleh Abu Lueng Angen semasa sehatnya. Diantaranya teungku/guru mampu menjadi teladan bagi santrinya. Seperti dalam hal mengajar, berpakaian, bersikap dan sebagainya. Karena ketika si anak ini (santri) sudah berada dalam lingkungan luar. Implementasi yang dicontohkan oleh teungku/guru biasanya akan tampak. Disinilah akan terlihat jelas gagal tidaknya teungku/guru menjadi teladan bagi santrinya. Peran teungku/guru juga pendorong kreatifitas dan pembaharu bagi santri $"{ }^{21}$

Kesimpulan hasil wawancara dari beberapa informa terkait peran teungku/guru dalam memberikan pelajaran di Dayah Darul Huda Lueng Angen, sebagai berikut:

(1) Kerja sama antara teungku/guru dan santri dalam berdiskusi

(2)Teungku/guru sebagai pembimbing, faisilitator, dan narasumber dalam proses belajar mengajar

(3)Teungku/guru

(4)Teungku/guru sebagai suri teladan, pendorong kreatifitas dan pembaharu bagi santri

\section{c. Strategi dan Metode Para Teungku/Guru Dalam Menambahkan Daya Tarik Minat Belajar Santri Pada Metode Meuulang (Muthala'ah)}

Berikut ini akan dipaparkan secara jelas hasil analisis transkip wawancara peneliti terhadap beberapa informan terkait dengan strategi dan metode para tuengku/guru dalam menambah daya tarik minat belajar santri pada metode meuulang (muthala'ah)di Dayah Darul Huda Lueng Angen;

Tgk Rahayu mengatakan:

"Strategi guru berinteraksi dengan santrinya dengan cara memberi motivasi dan memberi nasehat. Karena dengan memberikan motivasi dan nasehat membuat santri terbuka dengan pemikirannya. Dalam meuulang (muthala'ah) kedisiplinan dan hukuman sebagai tradisi yang dilakukan oleh para gure peuulang dengan menanamkan

${ }^{20}$ Hasil wawancara Tgk. Syahrial, Sabtu 05 Oktober 2019 "Tradisi Meuulang (Muthala'ah) Dalam Meningkatkan Interaksi Individual (Pendekatan Santri dan Teungku) di Dayah Darul Huda Lueng Angen, Kec. Langkahan Aceh Utara”

${ }^{21}$ Hasil wawancara Tgk. Rahayu, Sabtu 05 Oktober 2019 "Tradisi Meuulang (Muthala'ah) Dalam Meningkatkan Interaksi Individual (Pendekatan Santri dan Teungku) di Dayah Darul Huda Lueng Angen, Kec. Langkahan Aceh Utara” 
kedisiplinan dengan tampilan berbeda, sehingga terdapat daya tarik tersendiri dalam meuulang (muthala'ah)". ${ }^{22}$

Selanjutnya peneliti mewawancarai, Tgk. Triana tentang metode para tuengku/guru dalam menambah daya tarik minat belajar santri pada metode meuulang (muthala'ah) di Dayah Darul Huda Lueng Angen, mengatakan:

"setiap kelas berbeda-beda metode dalam menarik minat belajar santri dalam meuulang (muthala'ah) disini kreatifitas gure peulang sangat berpengaruh. Apabila gure peuulang tidak menyadari bahwa santrinya merasa jenuh bahkan tidak tertarik dengan meuulang(muthala'ah) yang diasuhnya. Maka PR seorang gure peuulang ialah mampu menambah daya tarik melalui metode yang harus diperbaharui atau komunikasi lebih dekat dengan santri. Seperti yang dilakukan oleh Tgk. AY sebelumnya kelas yang dia asuh dalam meuulang (muthala'ah) terkenal gagal dalam menumbuhkan minat santri. Bahkan cukup fatal santri bertingkah tidak menyukai meuulang (muthala'ah) dan sering bolos ketika masuk jadwal meuulang (muthala'ah). Hingga akhirnya kami selaku pihak kurikulum dan pemerhati aktivitas santri berunding kembali dengan gure peuulang lainnya dan kamipun menerapkan beberapa strategi seperti pembacaan bait alfiyah menggunakan irama, mengajak santri terlibat dalam segala hal bertopik meuulang (muthala'ah) dan sebagainya". ${ }^{23}$

Kemudian peneliti juga mewawancarai santriwati, menurut santriwati AI, mengatakan:

"Ada 2 gure peuulang favorit dalam kelas meuulang (muthala'ah), karena guru tersebut dapat berinteraksi dengan baik dan suasana meuulang (muthala'ah) menjadi menyenankan, yakni Tgk Tara dan Tgk Syarifah. Karena kedua guru tersebut memiliki metode pembelajaran yang menyenangkan yakni menggunakan metode ceramah dengan bahasa yang mudah dimengerti membuat santri mudah menangkap pelajaran yang diberikan". ${ }^{24}$

Kemudian mewawancarai santriwati $\mathrm{P}$, mengungkapkan:

"Meuulang (muthala'ah) mula-mulanya saya selaku santri baru tidak terlalu tertarik, ditambah lagi jadwalnya sudah larut malam. Namun setelah diikuti sesuai prosedur alhamdulillah buah manis daripada meuulang (muthala'ah) sudah saya dapati dan dengan adanya

\footnotetext{
${ }^{22}$ Hasil wawancara Tgk. Rahayu, Minggu 06 Oktober 2019 "Tradisi Meuulang (Muthala'ah) Dalam Meningkatkan Interaksi Individual (Pendekatan Santri dan Teungku) di Dayah Darul Huda Lueng Angen, Kec. Langkahan Aceh Utara”,

${ }^{23}$ Hasil wawancara Tgk. Trina, Minggu 06 Oktober 2019 "Tradisi Meuulang (Muthala'ah) Dalam Meningkatkan Interaksi Individual (Pendekatan Santri dan Teungku) di Dayah Darul Huda Lueng Angen, Kec. Langkahan Aceh Utara”

${ }^{24}$ Informan: santriwati AI, (06 Oktober 2019, 17:10 Wib)
} 
meuulang (muthala'ah) sangat membantu saya yang masih awam dalam pembelajaran". ${ }^{25}$

Dan terakhir peneliti mewawancarai santriwati S :

"Biasanya kami berani memulai berkomunikasi dari meuulang (muthala'ah) sehingga keakraban yang tercipta sangat membantu, terutama santriwati yang sedikit malas dikarenakan tidak bisa dalam satu belajar. Dengan meuulang (muthala'ah) kami para santriwati baru bisa membuang kemalasan belajar tersebut". ${ }^{26}$

Kesimpulan dari wawancara beberapa informan terkait strategi dan metode para tuengku/guru dalam menambah daya tarik minat belajar santri pada metode meuulang (muthala'ah)di Dayah Darul Huda Lueng Angen, mulai menanam kedisiplinan dan rasa tanggung jawab terhadap santri, lalu mengubah komunikasi dari terkesan kaku hingga menjadi ramah dan mudah dipahami santri. Mengajak santri terlibat dan menciptakan belajar mengajar menyenangkan diterapkan pula dayah Darul Huda Lueng Angen dalam menambah daya tarik minat santri dalam meuulang (muthala'ah). Berhasilnya suatu lembaga pendidikan dalam mendidik santri dapat dilihat dan dinilai ketika santri sudah menjadi alumni dan mampu mengembangkan ilmu pengetahuan agamanya selama dipodok untuk diterapkan dalam masyarakat

\section{Hasil Observasi}

\section{a. Interaksi Santri dan Teungku di Dayah Darul Huda Lueng Angen}

Berdasarkan hasil observasi peneliti terkait interaksi santri dan teungku di Dayah Darul Huda Lueng Angen, dapat disimpulkan bahwa interaksi santri dan teungku/guru di Dayah Darul Huda Lueng Angen berlangsung disebabkan adanya:

(1)Motivasi yang tinggi dari santri untuk belajar adalah salah satu indikator keberhasilannya interaksi.

(2)Keterampilan teungku dalam berinteraksi atau berkomunikasi dengan baik selama proses belajar mengajar berlangsung.

(3)Kerjasama antara santri dan teungku dalam pemecahan masalah

(4)Kebutuhan inklusi (individu mulai berpatisipasi dan bersosialisasi dengan lingkungannya) individu yang tidak terpenuhi kebutuhan inklusinya cenderung berperilaku malu, menarik diri, sulit menyesuaikan diri dan sulit bekerja sama dengan orang lain.

(5)Kebutuhan akan dorongan dan arahan (kontrol) dari orang lain dalam menyelesaikan setiap persoalan yang dihadapi.

(6)Kebutuhan afeksi merupakan kebutuhan dimana seseorang mendapatkan kasih sayang dan perhatian dari orang lain agar dapat diterima di dalam kelompok. Kebutuhan afeksi ini tercermin dengan timbulnya perasaan suka atau tidak suka dengan orang lain.

\footnotetext{
${ }^{25}$ Informan: santriwati P, (06 Oktober 2019, 17: $\left.40 \mathrm{Wib}\right)$

${ }^{26}$ Infoman: santriwati S, (06 Oktober 2019, 18: $\left.30 \mathrm{Wib}\right)$
} 
(7)Adanya kontak sosial, hubungan antara individu satu dengan individu yang lain yang bersifat langsung, seperti dengan sentuhan, percakapan, maupun tatap muka sebagai wujud aksi dan reaksi.

\section{b. Peran Teungku/guru Dalam Memberikan Pelajaran di Dayah Darul Huda Lueng Angen}

Berdasarkan hasil observasi peneliti, ada beberapa peran teungku/guru dalam memberikan pelajaran di Dayah Darul Huda Lueng Angen diantaranya kerja sama antara teungku/guru dan santri dalam berdiskusi, teungku/guru sebagai pembimbing, faisilitator, dan narasumber dalam proses belajar mengajar, Teungku/guru sebagai suri teladan, pendorong kreatifitas dan pembaharu bagi santri. Sehingga indikator pencapain maksimal terwujud dalam meuulang (muthala'ah)

\section{c. Strategi dan Metode Para Teungku/Guru Dalam Menambahkan Daya Tarik Minat Belajar Santri Pada Metode Meuulang (Muthala'ah)}

Metode merupakan salah satu pendukung untuk mencapai tujuan pendidikan, tanpa metode tidak akan berjalan lancar dan akan terjadi pengaruh besar bagi peserta didik dalam menerima pelajaran. Jadi setiap pendidik harus memiliki bermacam metode dalam mengajar. Begitupula halnya dengan metode yang diterapkan di di Dayah Darul Huda Lueng Angen. Guru dalam memberikan materi kepada santri menggunakan berbagai metode, seperti ceramah, tanya jawab, diskusi, dan demontrasi. Dalam memberikan ilmu pengetahuan terutama dalam bidang pendidikan agama Islam untuk membentuk karakter masyarakat yang didasari dengan nilai-nilai agama Islam dimana hasilnya dapat dilihat dari tindakan secara nyata seperti kejujuran, bertanggung jawab, toleransi, saling menghormati, budi pekerti, moral, membentuk akhlak yang terpuji, yang pada intinya memprioritaskan sikap seseorang dalam kehidupan kesehariaannya.

Pendidikan di Dayah Darul Huda Lueng Angen memang berbeda dengan pendidikan umum baik dari segi waktu dan pencapaian hasilnya. Di lembaga pendidikan umum waktu yang disediakan untuk proses belajar mengajar hanya beberapa jam saja, sedangkan di Dayah Darul Huda Lueng Angen hampir tidak ada waktu untuk tidak belajar. Selain itu peran lembaga ini dibidang pendidikan terutama sekali dpendidikan agama Islam juga telah memberikan andil yang besar karena ilmu agama sangat berguna baik didunia maupun diakhirat.

Pendidikan di Dayah Darul Huda Lueng Angen sebagian orang beranggapan bahwa proses menimba ilmu itu berjalan lamban tetapi sebenarnya tidak seperti itu dengan strategi yang ditetapkan begitu singkat, ternyata para santri mampu mengusai ilmu agama. Terutama bagi santri yang menetap didayah yang telah disediakan oleh pengurus yaitu dengan penerapan meuulang (muthala'ah) yang diwajibkan bagi setiap santri yang dibentuk dalam kelompok belajar.

Di Dayah Darul Huda Lueng Angen juga demikian, proses kegiatan belajar mengajar menerapkan sistem yang teratur dimana para santri melakukan wirid setelah shalat magrib berjamaah, membaca samadhiah dan tahlil setiap malam jumat. Selain kegiatan kurikuler, pimpinan dan pengurus dayah dalam 
memajukan pendidikan juga menerapkan kegiatan ekstra kurikuler seperti Dalael Khairad, dzikir dan berzanzi (meudike) dan sebagainya. Dalam bidang pendidikan ini para guru juga memberikan konstribusi dengan mendidik beberapa orang santri yang sudah tamat untuk menyampaikan dakwah tentang agama Islam dikampung halaman mereka.

Tabel 4.6 Jadwal Belajar di Dayah Darul Huda Lueng Angen 2019

\begin{tabular}{|l|l|l|l|}
\hline NO & \multicolumn{1}{|c|}{ WAKTU } & \multicolumn{1}{|c|}{ JAM BELAJAR } & \multicolumn{1}{c|}{ KET } \\
\hline 1 & Subuh & $05.30-07.00 \mathrm{WIB}$ & Selesai shalat subuh \\
\hline 2 & Dhuha & $09.00-10.30 \mathrm{WIB}$ & \\
\hline 3 & Dzuhur & $13.30-15.00 \mathrm{WIB}$ & Selesai shalat dzuhur \\
\hline 4 & Malam & $19.20-21.30 \mathrm{WIB}$ & Selesai shalat magrib \\
\hline 5 & Malam & $22.15-23.30 \mathrm{WIB}$ & Selesai shalat isya \\
\hline 6 & Malam & $23.30-01.15 \mathrm{WIB}$ & Jadwalmeuulang (muthala'ah) \\
\hline
\end{tabular}

Sumber Data: Kantor Tata Usaha Dayah Darul Huda, diolah 2019.

Berdasarkan data yang telah dikumpulkan, baik dari hasil wawancara maupun observasi yang telah peneliti lakukan, maka dapat dianalisa sebagaiberikut:

\section{a. Interaksi Santri dan Teungku di Dayah Darul Huda Lueng Angen}

Adapun interaksi berlangsung antara santri dan teungkumeliputi aktivitasaktivitas sebagai berikut:

(1) Motivasi yang tinggi dari santri untuk belajar adalah salah satu indikator keberhasilannya interaksi.

(2) Keterampilan teungku dalam berinteraksi atau berkomunikasi dengan baik selama proses belajar mengajar berlangsung.

(3) Kerjasama antara santri dan teungku dalam pemecahan masalah

(4) Kebutuhan inklusi (individu mulai berpatisipasi dan bersosialisasi dengan lingkungannya) individu yang tidak terpenuhi kebutuhan inklusinya cenderung berperilaku malu, menarik diri, sulit menyesuaikan diri dan sulit bekerja sama dengan orang lain.

(5) Kebutuhan akan dorongan dan arahan (kontrol) dari orang lain dalam menyelesaikan setiap persoalan yang dihadapi.

(6) Kebutuhan afeksi merupakan kebutuhan dimana seseorang mendapatkan kasih sayang dan perhatian dari orang lain agar dapat diterima di dalam kelompok. Kebutuhan afeksi ini tercermin dengan timbulnya perasaan suka atau tidak suka dengan orang lain.

(7) Adanya kontak sosial, hubungan antara individu satu dengan individu yang lain yang bersifat langsung, seperti dengan sentuhan, percakapan, maupun tatap muka sebagai wujud aksi dan reaksi.

b. Peran Teungku/guru Dalam Memberikan Pelajaran di Dayah Darul Huda Lueng Angen

Ada beberapa peran teungku/guru dalam memberikan pelajaran di Dayah Darul Huda Lueng Angen diantaranya kerja sama antara teungku/guru dan santri dalam berdiskusi, teungku/guru sebagai pembimbing, faisilitator, dan narasumber dalam proses belajar mengajar, Teungku/guru sebagai suri teladan, pendorong 
kreatifitas dan pembaharu bagi santri. Sehingga indikator pencapain maksimal terwujud dalam meuulang (muthala'ah).

\section{c. Strategi dan Metode Para Teungku/Guru Dalam Menambahkan Daya Tarik Minat Belajar Santri Pada Metode Meuulang (Muthala'ah)}

Adapun strategi dan metode para tuengku/guru dalam menambah daya tarik minat belajar santri pada metode meuulang (muthala'ah)di Dayah Darul Huda Lueng Angen, mulai menanam kedisiplinan dan rasa tanggung jawab terhadap santri, lalu mengubah komunikasi dari terkesan kaku hingga menjadi ramah dan mudah dipahami santri. Mengajak santri terlibat dan menciptakan belajar mengajar menyenangkan diterapkan pula dayah Darul Huda Lueng Angen dalam menambah daya tarik minat santri dalam meuulang (muthala'ah). Berhasilnya suatu lembaga pendidikan dalam mendidik santri dapat dilihat dan dinilai ketika santri sudah menjadi alumni dan mampu mengembangkan ilmu pengetahuan agamanya selama dipodok untuk diterapkan dalam masyarakat.

\section{Penutup}

Pendidikan yang ada di Dayah Darul Huda Lueng Angen sebagian orang beranggapan bahwa proses menimba ilmu disana berjalan lambat tetapi sebenarnya tidaklah seperti itu. Dengan strategi yang diterapkan ternyata para santri mampu mengusai pengetahuan agama terutama bagi santri yang menetap didayah yang telah disediakan oleh pengurus yaitu dengan penerapan cara meuulang (muthala'ah) yang diwajibkan bagi setiap santri yang dibentuk dalam kelompok belajar.

\section{Daftar Pustaka}

Abdullah, Tajussubki. Umdah: Hukum Wanita Musafir. Samalanga edisi XIV (April 2017)

Anas Sudjiono, Pengantar Statistik Pendidikan, (Jakarta: Rajawali Press, 2002)

Arikunto, Suharsimi. Prosedur Penelitian dan Praktinya. Yogjakarta: Rineka Cipta, 1993

Bambang Setiyadi, Metode Penelitian untuk Pengajaran Bahasa Asing Pendekatan Kuantitatif dan Kualitatif, (Yogyakarta: Graha Ilmu, 2006)

Bungin, Burhan. Metodologi Penelitian Kualitatif. Jakarta: Raja Grafindo Persada, 2005.

Bungin, Burhan. Metode Penelitian Kualitatif Aktualisasi Metodelogis ke Arah Ragam Varian Kontemporer. Jakarta: PT Raja Gravindo Persada, 2003.

Departemen Agama RI, Profil Pondok Pesantren Mu'adalah, (Jakarta: Direktorat Pendidikan Keagamaan dan Pondok Pesantren, 2004)

Moh. Nazir, Metode Penelitian, (Bogor: Ghalia Indonesia, 1983)

Mukhlisuddin Ilyas, Pendidikan Dayah Aceh: Mulai Hilang Identitas, (Banda Aceh: Bandar Publishing, 2012)

Mustafa Idris, Umdah: KB Dalam Pandangan Islam, (Samalanga: edisi XII, 2016

Sudjana, Nana. Dkk, Penelitian dan Nilai, (Bandung: Pendidikan Sinar, 1989)

Sukardi, Metodologi Penelitian Pendidikan, (Jakarta: PT Bumi Aksara, 2009) 
Tajussubki Abdullah, Umdah: Hukum Wanita Musafir, (Samalanga: edisi XIV, 2017)Wawancara Pribadi dengan Tgk Halimah (Gure Peuulang). Lhok Nibong, 21 Oktober 2018

Wawancara Pribadi dengan Tgk Nurul Badariah (Staf Pengajar Dayah Darul Huda, Lueng Angen Aceh Utara). Lhok Nibong, 1 Februari 2019

Wawancara Pribadi dengan Tgk Oki Ila Dermawan (Staf Pengajar MUDI Mesra Samalanga), 14 Mei 2019 via instagram.

Wawancara Pribadi dengan Tgk. Sulaiman, Lhok Nibong, 04 Oktober 2019

Wawancara Pribadi dengan, Tgk. H. Muhammad Jafar (Abi Jafar), Lhok Nibong 07 Oktober 2019

Wawancara Pribadi dengan, Tgk. Manskur, Lhok Nibong 04 Oktober 2019

Wawancara Pribadi dengan, Tgk Triana, Lhok Nibong 05 Oktober 2019

Wawancara Pribadi dengan, santriwati Ys dan Mh, Dayah Darul Huda Lueng Angen 05 Oktober 2019

Wawancara Pribadi dengan, Tgk Rahayu, Lhok Nibong 05 Oktober 2019

Wawancara Pribadi dengan, santriwati AI, Dayah Darul Huda Lueng Angen 06 Oktober 2019

Wawancara Pribadi dengan, santriwati P, Dayah Darul Huda Lueng Angen 06 Oktober 2019

Wawancara Pribadi dengan, santriwati S, Dayah Darul Huda Lueng Angen 06 Oktober 2019

Wawancara Pribadi dengan, Tgk Manskur, Lhok Nibong 05 Oktober 2019

Wawancara Pribadi dengan, Tgk Syahrial, Lhok Nibong 05 Oktober 2019

Yasmadi. Modernisasi Pesantren: Kritik Nurcholish Madjid Terhadap Pendidikan Islam Tradisional. Jakarta: Ciputat Press, 2005. 